\title{
A Scene of King Seti I from the Complex of Osiris at Abydos $^{1}$
}

\author{
Abd el Aziz Mohamed Hassan
}

Minia University

\begin{abstract}
This paper explores the representation of King Seti I onthe west wall of the first hall of in the complex of Osiris in his famous memorial temple at Abydos. This paper, also, the ritual of raising the Djed pillar as one of the main ceremonies of the New Kingdom.
\end{abstract}

Keywords:

Abydos -Egyptian Art - Seti I

\section{Introduction:}

Egyptian art reflects one of the most enduring artistic traditions of the ancient world. Although there were modification sin the style of Egyptian art during the 3,000 years when pharaohs ruled the Nile Valley, objects from any period of this time are instant lyre cognizable as being of Egyptian origin. ${ }^{2}$

What is called Egyptian art was originally created for religious and magical purposes. Its symbols and functions reveal the Egyptians' beliefs about the world and their attempts to understand and relate to it. In the Egyptian social and religious context, works of art played a practical role, whose straightforward physicality is not easy for the modern viewer to realize.

For example, the reliefs on temple walls depicting the king making offerings to the gods and smiting Egypt's enemies not only communicated the idea that the king was fulfilling his duty to maintain order in the universe. Egyptians also believed that these

${ }^{1}$ This paper is a part of a dissertation submitted in partial fulfillment of the requirements of master degree in Tourist Guidance, Faculty of Tourism and Hotel Management, Minia University, "Study of king representation scenes "in miniature form "Through Study of King Amenhotep III scenes at Luxor Temple and King SetiI at Abydos" under the supervision of Prof. Dr. Ahmad M. Abo el Magd, Minia, 2019.

${ }^{2}$ Emily Teeter, (1994), Egyptian Art, Art Institute of Chicago Museum Studies, Vol. 20, No. 1, Ancient Art at The Art Institute of Chicago, 15. [14-31]. 
مجلة و ادي النيل للار اسات و البحوث الإنسانية و الاجتماعية والتربوية (مجلة علمية محكمة)

(ISSN : 2536 - 9555)

images, through their very existence, were instrumental in making this order a reality. ${ }^{3}$

In New Kingdom ritual scenes, the royal image is portrayed in a variety of stances. Usually, pharaoh stands fully erect while performing a ritual act, for example when offering incense or a libation. The second, most common pose shows him kneeling with his knees together. Some other postures were used in ritual episodes, but they are seen less often. Usually, standing royal figures are shown leaning forward or stooping, while a kneeling one may either be semi-prostrate with his knees spread apart or have his torso inclined forward. ${ }^{4}$

\section{Discussion:}

\section{Scene Location:}

Osiris complex, first hall, West wall, lower register

\section{Description:}

King Seti I, assisted by Isis, raises the died-pillar

A small figure of the King Seti I, wearing the White Crown, kneels at the base of the pillar. Isis is entitled "Lady of Heaven, Mistress of the Two Lands", and grants the king her protection. The scene has no title but obviously represents the rite of "Raising the died-pillar".

The text reads:

\section{Behedety:}

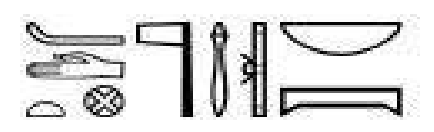

BHdty nTr aA nb pt

Behedety, the great god, master of heaven

${ }^{3}$ Watts, Edith W. (1998) The Art of Ancient Egypt, A resource for educators, The Metropolitan Museum of Art, 19-20.

${ }^{4}$ Brand, P., (2000) The Monuments of Seti I, Epigraphic, Historical and Art Historical Analysis, Leiden, 8. 
مجلة وادي النيل للار اسات والبحوث الإنسانية والاجتماعية والتربوية (مجلة علمية محكمة)

The king:

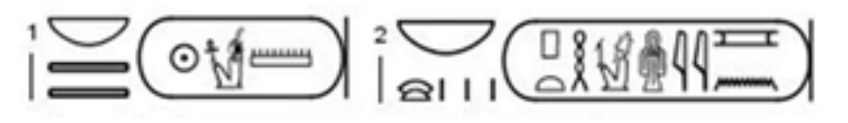

1-nb tAwy (Mn-MAat-Ra )| 2- nb xaw (Sty mry n PtH)|

Lord of the Two Lands (Men-Maat-Re)|, lord of the Crowns (Seti Meren- Ptah)|

\section{Osiris:}

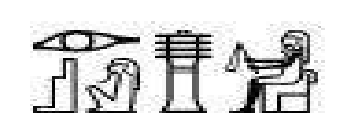

Wsir Dd Sps

The noble Djed pillar of Osiris

Isis:

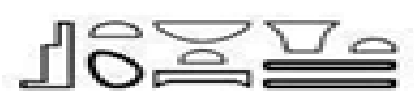

Ast nbt pt, Hnwt tAwy

Isis, mistress of the sky, mistress of the two lands.

\section{In front of Isis:}

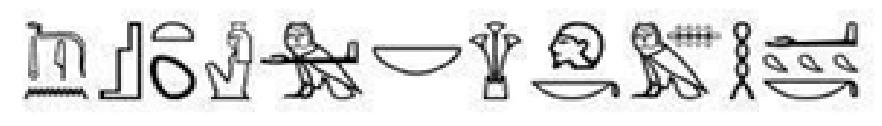

Dd mdw in Ast, mk HA .k m sA Haw .k

Words spoken by Isis: Look, (I) surround your head in protection of your limbs. 
مجلة وادي النيل للاراسات والبحوث الإنسانية و الاجتماعية والتربوية (مجلة علمية محكمة)

(ISSN : 2536 - 9555)

\section{Left marginal column:}

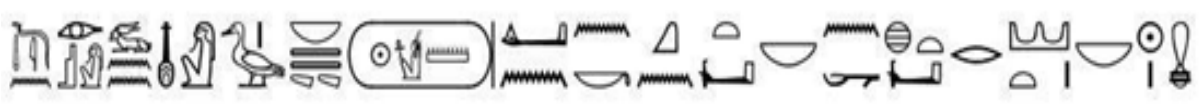

Dd mdw in Wsir Wnn-nfr, sA .i nb tAwy (Mn-MAat-Ra)| di n (.i) n .k qn nb, nxt nb r xAst nb mi Ra

Words spoken by Osiris-Ounennefer, Oh my son, Lord of the Two Lands

(Men-Maat-Re)|, (I) gave to you all bravery and victory over all foreign

countries, like Rea.

\section{Comments and Conclusion:}

The djed pillar was an important part of the ceremony called "raising the djed", which was a part of the celebrations of Heb Sed, the Egyptian king's jubilee celebrations. The act of raising the djed has been explained as representing Osiris's triumph over Set. Ceremonies in Memphis are described where the king, with the help of the priests, raised a wooden djed column using ropes. ${ }^{5}$

The ceremony took place during the period when fields were sown and the year's agricultural season would begin corresponding to the month of koiak, the fourth month of the inundation season called akhet. This ceremony was a part of one of the more popular holidays and celebrations of the time, a larger festival dedicated to Osiris conducted from the $13^{\text {th }}$ to the $30^{\text {th }}$ day of the khoiak month. ${ }^{6}$

Celebrated as it was at that time of the year when the soil and climate were most suitable for agriculture, the festival and its ceremonies can be seen as an appeal to Osiris, who was the God of

${ }^{5}$ Clark R. T. , (1991) Myth and Symbol in Ancient Egypt, London, 235-36; Wilkinson, R. H., (1992) Reading the Egyptian Art, A hieroglyphic Guide to Ancient Egyptian Painting and Sculpture, London, 165.

${ }^{6}$ Famhmey, M. A. (2018) "Scenes of the Djed Pillar during the New Kingdom: An Archeological and Analytical Study", unpublished MA thesis, Minia University, 85; Mikhail, L. B., (1984) "Raising the Djed-Pillar: The Last Day of the Osirian Khoiak Festival", GM83, 51-69. 
مجلة وادي النيل للار اسات والبحوث الإنسانية والاجتماعية والتربوية (مجلة علمية محكمة)

vegetation, to favor the growth of the seeds sown, paralleling his own resurrection and renewal after his murder by Seth .

The permanence of Egypt's artistic tradition can be traced to the function of its art. Virtually all examples of two-dimensional workwhether wall painting or carved relief-and all examples of statuary and architecture are related in some way to religious beliefs pertaining to Egyptian mortuary cults or to the veneration of the gods and kings.

The art reached a high level of Excellency and performance during the reign of King Seti I as can be observed from his master art of relief on the walls of his pyramid at Abydos.

\section{Bibliography:}

Brand, P., (2000) The Monuments of Seti I, Epigraphic, Historical and Art Historical Analysis, Leiden, 8.

Clark R. T., (1991) Myth and Symbol in Ancient Egypt, London, 23536.

Fahmey, M. A. (2018) "Scenes of the Djed Pillar during the New Kingdom: An Archeological and Analytical Study", unpublished MA thesis, Minia University.

Mikhail, L. B., (1984) "Raising the Djed-Pillar: The Last Day of the Osirian Khoiak Festival", GM 83, 51-69.

Teeter, E., (1994) Egyptian Art, Art Institute of Chicago Museum Studies, Vol. 20, No. 1, Ancient Art at The Art Institute of Chicago, 14-31.

The Oriental Institute of the University of Chicago(1938), The Temple of King Sethos I at Abydos, Volume III: The Osiris Complex, Chicago,

Watts, E. W. (1998) The Art of Ancient Egypt, A resource for educators, The Metropolitan Museum of Art, 19-20.

Wilkinson, R. H., (1992) Reading the Egyptian Art, A hieroglyphic Guide to Ancient Egyptian Painting and Sculpture, London. 
مجلة وادي النيل للاراسات والبحوث الإنسانية والاجتماعية والتربوية (مجلة علمية محكمة)

(ISSN : 2536 - 9555)

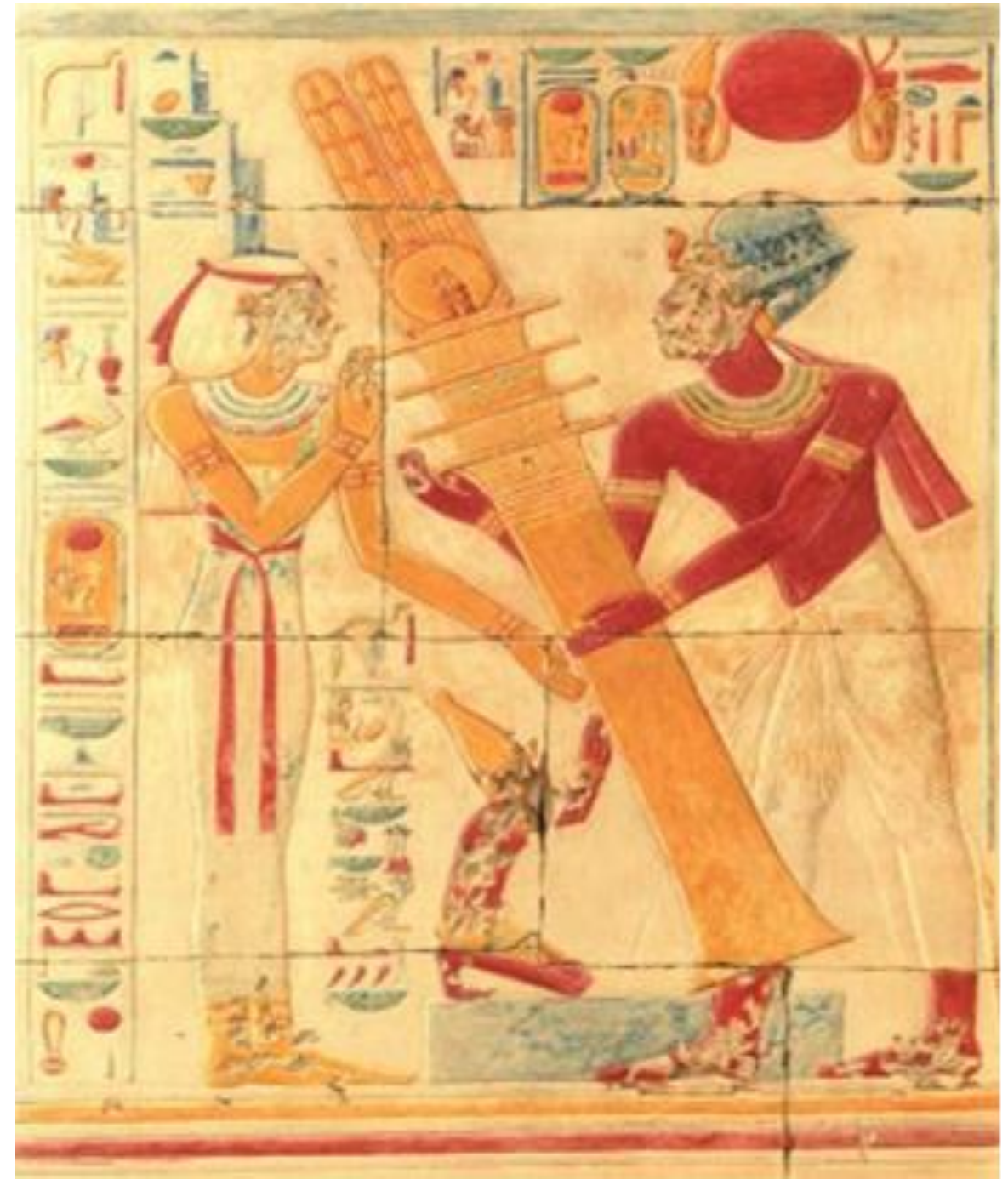

Complex of Osiris, Inner Osiris Hall, west wall, $3^{\text {rd }}$ section from the north lower

The Oriental Institute of the University of Chicago(1938), The Temple of King Sethos I at Abydos, Volume III: The Osiris Complex, Chicago, pl.8. 